\title{
Література:
}

1. A. Truyol y Serra. Doctrines contemporaines du droit des gens. Cours IHEI. Paris: 1952. C. 6.

2. Ch. Rousseau. Principes de droit international public. RCADI. 1958. C. 375.

3. Ch. Rousseau. Les conceptions nationales du droit des gens. Pedone. Paris: 1981. P. 441-446.

4. F. Despagnet. Cours de droit international public. Librairie générale des lois et arrêts. Paris: 1905. № 3. P. 6.

5. Jouannet Emmanuelle. Regards sur un siècle de doctrine française $\mathrm{du}$ droit international. Annuaire français de droit international. 2000. № 46. P. 1-57.

DOI https://doi.org/10.30525/978-9934-26-040-7-62

\section{ДЖЕРЕЛА ЕКОЛОГО-ПРАВОВОГО ЛІМІТУВАННЯ СКИДАННЯ РЕЧОВИН У ЗАКОНОДАВСТВІ ЄС ТА УКРАЇНИ}

\author{
Уберман B. I. \\ кандидат технічних наук, \\ провідний науковий співробітник лабораторї формування \\ та регулювання якості вод \\ Науково-дослідної установи \\ «Украӥнський науково-дослідний інститут екологічних проблем» \\ м. Харків, Украӥна \\ Васьковець Л. А. \\ кандидат біологічних наук, доцент, \\ професор кафедри безпеки праиі і навколишнього середовища \\ Начіонального технічного університету \\ «Харківський політехнічний інститут» \\ м. Харків, Украӥна
}

1. У документі державної екологічної політики України $[1$, p. 1] (Стратегія) серед головних проблем вказано забруднення вод, значне місце в якому займають «скиди 3 промислових об'єктів». Боротьба зі скидами речовин включає заходи щодо забезпечення якості води та 
поступового припинення скидання неочищених вод, щодо зменшення надходження промислового забруднення у водні об'єкти, а також зниження рівня їх забруднення. Передбачено розроблення відповідних законопроєктів, нормативно-правових актів та програмних документів, пов'язаних із наближенням законодавства України до права СС, визначених міжнародними зобов'язаннями. Адекватними еколого-правовими засобами зменшення забруднення слід визнати удосконалення інструментів законодавчого впливу на джерела техногенних скидів забруднювальних речовин (ЗР), подібного до європейського екосистемного підходу. Лімітування скидання ЗР належить до найбільш дієвих правових заходів охорони навколишнього природного середовища i забезпечення якості вод (як характеристики складу і властивостей води, яка визначає іiі придатність для конкретних цілей використання). Більшість ефективних правових важелів охорони поверхневих вод та забезпечення їх якості зосереджено в підінститутах регулювання скидання забруднювальних речовин (РСЗР) еколого-правових комплексних інститутів якості вод та іiі регулювання екологічного законодавства ЄС та водного законодавства України [2]. Ядро РСЗР утворюється законодавчими вимогами до обмеження скидання (або емісії) у воду хімічних речовин (ХР), які надходять із точкових джерел, тобто лімімаційним регулюванням. Відповідно до ст. 2(38)(b) Водної рамкової директиви СС (ВРД) [3] надходження ХР $\boldsymbol{y}$ поверхневу воду зі скиданням стічної води вважається наслідком одного $з$ видів «водних послуг». 3 іншого боку, імплементація в українське екологічне законодавство ключових еколого-правових категорій та понять законодавства $Є С$ належить до важливих наукових проблем, які підлягають вирішенню на шляху співробітництва України та СС у галузі охорони навколишнього середовища i, зокрема, водних ресурсів. За ст. 361 Угоди про асоціацію [4] «збереження, захист, поліпшення і відтворення якості навколишнього середовища» визнано першою складовою мети співробітництва України та ЄС. Тобто законодавче забезпечення європейського ставлення до якості довкілля $\epsilon$ головною ціллю імплементації. Співробітництво серед іншого здійснюється у сферах якість води та управління водними ресурсами, промислового забруднення і промислової загрози, хімічних речовин. На етапі трансформації українського екологічного законодавства важливою проблемою $є$ чітке визначення джерельної бази європейського та українського підінститутів РСЗР та хоча б тимчасова їі фіксація.

2. Великий обсяг та різнорідний зміст європейських та українських джерел законодавства, які містять норми відповідних підінститутів РСЗР, змушує при дослідженні поділити їх на джерела загальних та 
спеціальних вимог (норм). Спеціалізація визначається за галуззю відносин, що регулюються, та видами водокористування. Головним критерієм поділу загальних та спеціальних норм щодо лімітування скидання речовин слід вважати поширення вимог до складу та властивостей води (ще забирається, зворотної чи поверхневої) лише на один конкретний вид водокористування у межах предмету регулювання норми або акту. Джерела правових норм можуть знаходитися не тільки у підпорядковувальному («загальний $\rightarrow$ спеціальний») правовому зв'язку, а й бути паралельно чинними, незалежними, або, навіть, перетинатися між собою. Спеціалізація правового регулювання може здійснюватися у формах конкретизації, диференціації та інтеграції [5].

3. 3 результатів аналізу випливає, що підінститут РСЗР, встановлений у загальних джерелах екологічного законодавства ЄС, включає наступні директиви: ВРД [3]; Директива 2010/75/СС про промислові викиди (інтегрований підхід до запобігання забрудненню та його контролю); Directive 2008/105/EC, on environmental quality standards in the field of water policy; Директива 2006/11/ЄC про забруднення, спричинене деякими небезпечними речовинами, що скидаються до водного середовища; Directive 2013/39/EU «amending Directives 2000/60/EC and 2008/105/EC as regards priority substances in the field of water policy». Корисним джерелом деяких понять щодо РСЗР $\epsilon$ Regulation (EC) No 166/2006 concerning the establishment of a European Pollutant Release and Transfer Register.

3 точки зору спеціалізації стосовно РСЗР за наведеним критерієм до джерел спеціальних вимог у законодавстві СС наразі належать: Директива Ради 91/271/СЕС «Про очистку міських стічних вод»; Директива Ради щодо захисту вод від забруднення, спричиненого нітратами $з$ сільськогосподарських джерел (91/676/СЕС); Директива Ради 98/83/ЄС про якість води, призначеної для споживання людиною; Directive 2006/7/EC concerning the management of bathing water quality; Directive 2009/147/EC on the conservation of wild birds.

4. В українському законодавстві (у широкому значенні) джерелами загальних вимог до РСЗР є Закон України «Про охорону навколишнього природного середовища», Водний кодекс України та наступні підзаконні акти: «Правила охорони поверхневих вод від забруднення зворотними водами» (затв. постановою Кабінету Міністрів України від 25 березня 1999 р. № 465); «Про затвердження Порядку розроблення нормативів гранично допустимого скидання забруднюючих речовин у водні об'єкти та перелік забруднюючих речовин, скидання яких у водні об'єкти нормується» (затв. постановою Кабінету Міністрів України від 246 
11 вересня 1996 р. № 1100 (в редакції Постанови КМ № 1091 (1091-2017-п) від 13.12.2017; «Правила охорони внутрішніх морських вод і територіального моря України від забруднення та засмічення» (затв. постановою Кабінету Міністрів України від 29 лютого 1996 р. № 269 (у редакції постанови Кабінету Міністрів України від 29 березня 2002 р. № 431); «Порядок ведення державного обліку водокористування» (затв. наказом Міністерства екології та природних ресурсів України 16.03.2015 № 78; зареєст. в Міністерстві юстиції України 03 квітня 2015 р. за № 382/26827); «Методика віднесення масиву поверхневих вод до одного 3 класів екологічного та хімічного станів масиву поверхневих вод, а також віднесення штучного або істотно зміненого масиву поверхневих вод до одного з класів екологічного потенціалу штучного або істотно зміненого масиву поверхневих вод» (затв. наказом Міністерства екології та природних ресурсів України 14 січня 2019 року № 5; зареєст. в Міністерстві юстиції України 05 лютого 2019 р. за № 127/33098); «Інструкція про порядок розробки та затвердження гранично допустимих скидів (ГДС) речовин у водні об'єкти із зворотними водами» (затв. наказом Міністерства охорони навколишнього природного середовища України від 15 грудня 1994 р. № 116).

Спеціальними джерелами щодо вимог до РСЗР слід вважати наступні: Закон України «Про забезпечення санітарного та епідемічного благополуччя населення»; Закон України «Про питну воду, питне водопостачання та водовідведення»; Закон України «Про тваринний світ»; Закон України «Про аквакультуру»; Закон України «Про рибне господарство, промислове рибальство та охорону водних біоресурсів»; Закон України «Про рослинний світ»; Закон України «Про природно-заповідний фонд України», та велика кількість відповідних підзаконних актів.

Наведені джерела законодавчих вимог до РСЗР створюють можливості для визначення змісту, обсягу та послідовності завдань порівняльного дослідження європейського та українського відповідних еколого-правових підінститутів 3 метою першочергової гармонізації поняттєво-категоріального апарату в рамках поетапної імплементації, передбаченої [4], і реалізації вимог Стратегії.

\section{Література:}

1. Основні засади (стратегія) державної екологічної політики України на період до 2030 року (затв. Законом України від 28 лютого 2019 року № 2697-VIII). URL: https://zakon.rada.gov.ua/laws/show/269719\#Техt (дата звернення 25.01.2021). 
2. Уберман В. І., Васьковець Л. А. Поетапне наближення українського еколого-правового інституту якості вод та іiі регулювання до законодавства Європейського Союзу. Chap. in book: Legislation of EU countries: history, shortcomings and prospects for the development : Collective monograph. Frankfurt (Oder) : Izdevniecība «Baltija Publishing», 2019. P. 334-354. URL: https://core.ac.uk/download/pdf/304678851.pdf (дата звернення 25.01.2021).

3. Директива 2000/60/ЄС Європейського Парламенту і Ради «Про встановлення рамок діяльності Співтовариства в галузі водної політики» від 23 жовтня 2000 року. URL: https://zakon.rada.gov.ua/ laws/show/994_962\#Text (дата звернення 25.01.2021).

4. Угода про асоціацію між Україною, 3 однієї сторони, та Європейським Союзом, Європейським співтовариством 3 атомної енергії і їхніми державами-членами, 3 іншої сторони: Документ 984_011. Ред. від 30.11.2015. URL: https://zakon.rada.gov.ua/laws/ show/984_011 (дата звернення: 25.01.2021).

5. Подцерковний О. П. Загальні та спеціальні норми: проблеми виявлення та вирішення конкуренції. Вісник господарського судочинства. 2009. № 6. C. 34-43. URL: https://coordynata.com.ua/ zagalni-ta-specialni-normi-problemi-viavlenna-ta-virisenna-konkurencii (дата звернення: 25.01.2021).

DOI https://doi.org/10.30525/978-9934-26-040-7-63

\title{
ДО ПИТАННЯ ВІДПОВІДНОСТІ НОРМ НАЦІОНАЛЬНОГО ЗАКОНОДАВСТВА НОРМАМ МІЖНАРОДНОГО У СФЕРІ ПРОТИДІЇ ТА ЗАПОБІГАННЯ КОРУПЦІї
}

\author{
Щерба В. Ю. \\ магістр права, \\ уповноважена з антикорупиійної діяльності \\ Державної установи «Територіальне медичне об'єднання \\ Міністерства внутрішніх справ Украӥни по Вінниџькій області» \\ м. Вінниия, Украӥна
}

Ще від моменту створення першої держави корупція була «незмінною константою» у відносинах «держава-суспільство» та 